\title{
MODEL PENTAHELIK DALAM PENGEMBANGAN PARIWISATA DI KOTA SEMARANG
}

\author{
Tri Yuniningsih \\ Fakultas ilmu Sosial dan Ilmu Politik, Universitas Diponegoro, triyuningsih67@yahoo.com \\ Titi Darmi \\ Universitas Muhammadiyah Bengkulu, titi.harmadi@gmail.com \\ Susi Sulandari \\ Fakultas ilmu Sosial dan Ilmu Politik, Universitas Diponegoro
}

\begin{abstract}
Abstrak
Tujuan Penelitian mendeskripsikan model pentahelix dalam pengembangan pariwisata di kota Semarang. Permasalahannya adalah kurang optimalnya kerjasama antar aktor yang terlibat. Teori menggunakan Teori Aktor Kebijakan dan Model Pentahelix. Jenis penelitian deskriptif, pendekatan kualitatif. Data dikumpulkan melalui: wawancara, observasi dan kepustakaan. Penentuan informan dengan teknik Snowball dan key informan Kepala Dinas Pariwisata dan Kebudayaan kota Semarang. Analisis data dengan cara: kondensasi data, verifikasi data dan penarikan kesimpulan . Validasi data menggunakan triangulasi sumber. Dari penelitian dapat diketahui : (1) Pengembangan pariwisata kota Semarang menggunakan model pentahelix, sudah melibatkan akademisi, pemerintah, komunitas, bisnis, dan media massa (2)Temuan lapangan adalah Badan Promosi Pariwisata Kota Semarang (BP2KS) belum optimal dan (3)Kerjasama antar aktor model pentahelix yang ada di kota Semarang dari hasil penelitian belum optimal. Rekomendasi penelitian: dilakukan revisi terhadap perda kepariwisataan kota Semarang yang menyangkut "kerjasama antar aktor, penguatan kapasitas kelembagaan BP2KS, dan peneliti berikutnya disarankan mengambil fokus penelitian dengan lokus yang berbeda atau melakukan perbandingan dengan fokus yang sama.
\end{abstract}

Kata kunci: Pentahelix,Pengembangan,Pariwisata.

\begin{abstract}
Objective The study describes the pentahelix model in tourism development in the city of Semarang. The problem is the lack of optimal cooperation between the actors involved. Theory uses the Policy Actor Theory and the Pentahelix Model. Descriptive research type, qualitative approach. Data is collected through: interview, observation and literature. Determination of informants with Snowball technique and key informants Head of the Department of Tourism and Culture of the city of Semarang. Data analysis by means of: data condensation, data verification and conclusion drawing. Data validation uses source triangulation. From the research it can be seen: (1) tourism development in Semarang city using pentahelix model, has involved academics, government, community, business, and mass media (2) Field findings are the Semarang City Tourism Promotion Agency (BP2KS) is not optimal and (3) Cooperation between the pentahelix model actors in the city of Semarang from the results of the research is not optimal. Research recommendations: revised the tourism regulation of Semarang city concerning "collaboration between actors, strengthening the institutional capacity of BP2KS, and subsequent researchers are advised to take the focus of research with different loci or make comparisons with the same focus.
\end{abstract}

Keywords: Pentahelix, Development, Tourism 


\section{PENDAHULUAN}

Keuntungan dari dilaksanakannya otonomi daerah adalah setiap daerah memiliki keleluasaan untuk mengembangkan dan mengelola daerahnya sendiri sesuai dengan potensi yang dimilikinya. Berkaitan dengan pelimpahan kewenangan pusat kepada daerah adalah dalam hal pengelolaan sektor pariwisata. Dengan otonomi daerah setiap daerah akan cenderung mementingkan peningkatan Pendapatan Asli Daerah, sehingga pertimbangan kelestarian lingkungan dan pelibatan masyarakat lokal menjadi terabaikan. Oleh karena itu diperlukan kearifan daerah untuk menyikapi pembangunan secara holistik sehingga terwujud pemerataan dalam kemajuan ekonomi, ekologi, dan keadilan sosial. Dinamika kehidupan bangsa sekarang sangat dipengaruhi oleh kondisi global pengembangan pariwisata, sehingga dituntut mampu menghadapi segala keadaan buruk, seperti dampak gejolak politik, krisis ekonomi, dan sebagainya. Disinilah perlunya dukungan semua pihak, sehingga pengembangan pariwisata tidak hanya menjadi tanggung jawab pemerintah saja.

Dalam rangka melaksanakan ketentuan Pasal 8 ayat (1) dan Pasal 9 ayat (3) UndangUndang Kepariwisataan No. 10 Tahun 2009 tentang Kepariwisataan, dan Pasal 8 ayat (3) Perda Kota Semarang No. 3 Tahun 2010 tentang Kepariwisataan maka ditetapkan Perda Kota Semarang no.5 tahun 2015 tentang Rencana Induk Pembangunan Kepariwisataan Kota Semarang tahun 2015 - 2025. Regulasi tersebut sebagai dasar pelaksanaan kegiatan kepariwisataan guna meningkatkan daya saing Kota Semarang yang dilandasi nilai-nilai budaya bangsa dan kearifan lokal masyarakat yang dilakukan secara sistematis, terencana, terpadu, berkelanjutan, dan bertanggung jawab dengan tetap memberikan perlindungan terhadap nilainilai agama,budaya yang hidup dalam masyarakat, kelestarian dan mutu lingkungan hidup, serta kepentingan nasional. Rencana Induk Pembangunan Kepariwisataan Kota (RIPARKOT) Semarang Tahun 2015 - 2025 tertuang Visi pembangunan kepariwisataan kota sebagaimana dimaksud dalam Pasal 4 huruf (a) adalah Semarang sebagai Destinasi Pariwisata yang berdaya saing, berkelanjutan, mampu mendorong pembangunan, dan meningkatkan kesejahteraan rakyat. Faktor yang menjadi indikasi kurang optimalnya pengembangan pariwisata kota Semarang dapat dilihat dari Evaluasi Renstra Dinas Kebudayaan dan Pariwisata 2011 - 2015 yang dilaksanakan tahun 2016, pada saat pelaksanaan program/kegiatan pada sasaran pengembangan kemitraan dengan pelaku usaha pariwisata dan Pemerintah Daerah lainnya terdapat kendala yang dihadapi sebagai berikut: (1) terbatasnya jumlah media bahan dan promosi kepariwisataan Kota Semarang dan (2) kurang koordinasi dengan asosiasi pelaku usaha pariwisata, khususnya biro-biro perjalanan wisata (Yuniningsih,2018). Berkaitan dengan kerjasama dalam pengembangan pariwisata di kota Semarang, dengan mengacu pada UU Nomor 10 Tahun 2009 tentang Kepariwisataan Bab IX, Bab X dan Bab XI yang kemudian ditindaklanjuti dengan Perda kota Semarang Nomor 3 tahun 2010 tentang Kepariwisataan, Bab X, Bab XI dan Bab XII dapat diketahui bahwa kerjasama dan kemitraan serta koordinasi antar aktor yang terlibat sudah diatur dengan jelas. Permasalahan utama sehingga penelitian ini perlu dilakukan adalah kerjasama antar aktor yang terlibat dalam pengembangan pariwisata di kota Semarang masih belum optimal. Penelitian ini bertujuan untuk mendeskripsikan bagaimana model kerjasama pengembangan pariwisata di kota Semarang.

Tabel 1. Jumlah Wisatawan Kota Semarang

\begin{tabular}{|l|l|l|l|l|l|l|}
\hline $\begin{array}{l}\text { Ta } \\
\text { hu } \\
\text { nis }\end{array}$ & $\begin{array}{l}\text { man } \\
201\end{array}$ & 392. & 0 & $\begin{array}{l}\text { Wisn } \\
\text { us }\end{array}$ & Total & $\%$ \\
3 & 895 & & 8.351 & & 1.246 & \\
\hline 201 & 372. & - & 25.24 & 15 & 25.61 & 15 \\
4 & 463 & 5. & 0.021 &, 5 & 2.484 &, 2 \\
& & 2 & & 8 & & 1 \\
& & 0 & & & & \\
\hline 201 & 388. & 4. & 29.43 & 16 & 29.81 & 16 \\
5 & 143 & 2 & 0.609 &, 6 & 8.752 &, 4 \\
& & 1 & & 0 & & 2 \\
\hline 201 & 419. & 8. & 29.85 & 1, & 30.27 & 1, \\
6 & 584 & 1 & 2.095 & 43 & 1.679 & 52 \\
& & 0 & & & & \\
\hline 201 & 421. & 0. & 33.03 & 10 & 33.45 & 10 \\
7 & 191 & 3 & 0.843 &, 6 & 2.034 &, 5 \\
& & 8 & & 5 & & 1 \\
\hline
\end{tabular}




\section{Sumber: Data Dinas Kebudayaan} dan Pariwisata Kota Semarang 2018

Dari tabel di atas dapat diketahui bahwa jumlah pengunjung memang angkanya meningkat dari tahun ke tahun, akan tetapi bila dilihat dari persentase ternyata mengalami naik turun atau tidak stabil. Bila dilihat pada Wisman pada tahun 2013 ke tahun 2014 terjadi penurunan 5,20\%, kemudian pada tahun 2014 ke tahun 2015 terjadi kenaikan 4,21\%, pada tahun 2015 ke tahun 2016 meningkat $8,10 \%$ dan pada tahun 2016 ke tahun 2017 meningkat 0,38\%. Untuk wisnus dapat diketahui bahwa pada tahun 2013 ke tahun 2014 mengalami kenaikan 15,58\%, tahun 2014 ke tahun 2015 mengalami kenaikan 16,60\%, tahun 2015 ke tahun 2016 mengalami kenaikan 1,43\% dan tahun 2016 ke tahun 2017 mengalami kenaikan 10,65 \%. Naik turunnya jumlah pengunjung di atas menjadikan indikasi kelemahan dalam pengembangan pariwisata di Kota Semarang. Hal ini juga didukung dengan data jumlah kunjungan wisatawan berdasarkan data RPJMD Perubahan 2017 sebagai berikut;

Tabel 2. Capaian Kinerja Jumlah Kunjungan Wisatawan

\begin{tabular}{|c|c|c|c|c|c|}
\hline $\begin{array}{l}\text { indi } \\
\text { kato } \\
\mathbf{r}\end{array}$ & $\begin{array}{l}\text { Kon } \\
\text { disi } \\
\text { Awa } \\
\text { l } \\
2015\end{array}$ & $\begin{array}{l}\text { Targe } \\
\text { t } \\
\text { Kiner } \\
\text { ja } \\
\text { Akhir } \\
\text { RPJ } \\
\text { MD }\end{array}$ & $\begin{array}{l}\text { Realis } \\
\text { asi } \\
\text { Kiner } \\
\text { ja } \\
2016\end{array}$ & $\begin{array}{l}\text { Cap } \\
\text { aian } \\
\text { kine } \\
\text { rja } \\
\text { terh } \\
\text { ada } \\
\text { p } \\
\text { targ } \\
\text { et } \\
\text { akhi } \\
\text { r } \\
\text { RPJ } \\
\text { MD }\end{array}$ & $\begin{array}{l}\text { Sta } \\
\text { tus } \\
\text { cap } \\
\text { aia } \\
\text { n }\end{array}$ \\
\hline $\begin{array}{l}\text { juml } \\
\text { ah }\end{array}$ & $\begin{array}{l}4.37 \\
6.35 \\
9\end{array}$ & $\begin{array}{l}6.847 . \\
543,0 \\
0\end{array}$ & $\begin{array}{l}4.683 . \\
974,0 \\
0\end{array}$ & $\begin{array}{l}68,4 \\
0 \%\end{array}$ & $\begin{array}{l}\text { sed } \\
\text { ang }\end{array}$ \\
\hline
\end{tabular}

Sumber: RPJMD Kota Semarang (Perubahan), 2017

Tabel di atas menunjukkan bahwa capaian kinerja berkaitan dengan jumlah kunjungan wisatawan sebesar $68,40 \%$ atau dalam status sedang. Hal ini semakin memperkuat indikasi dimana belum optimalnya Pengembangan pariwisata di Kota
Semarang.

Penelitian terdahulu yang relevan dan mendukung penelitian ini adalah (1) Dang Wang, John Ap, 2013, Faktor Affecting Tourism Policy Implementation: Conceptual Framework and Case Study in China. Journal of Tourism Management, (36), 221-233. (2) Chui, Hua Lie et al., 2012, Improving Tourism Policy Implementation : The Use of Hybrid MCDM Model, Tourism Management, (33), 413-426.(3) Victoria M. Waligo, Jackie Clarke, Rebecca Hawkin, 2012, Implementing Sustainable Tourism: Multi Stakeholder Involvement Management (MSIM) Framework, Tourism Managemant, 30, 1-12.dan (4) Tobias Bach ( 2012), The involvement of agencies in policy formulation : Explaining variation in policy autonomy of federal agencies in Germany. Dibandingkan beberapa penelitian terdahulu kebaruan penelitian ini adalah penggunaan model Penthahelix yang belum diteliti sebelumnya. Teori dasar yang dipakai dalam penelitian ini adalah Teori aktor kebijakan \{Howlett dan Rames (1995), dalam Suwitri(2011)\} dan Model Penthahelix (Arif Yahya, 2016).

\section{METODE PENELITIAN}

Pendekatan penelitian ini menggunakan pendekatan kualitatif. Tipe penelitian adalah penelitian deskriptif yaitu penulisan yang berisi uraian tentang suatu objek sebagaimana adanya waktu tertentu, untuk memaparkan secara rinci serangkaian data yang diperoleh melalui observasi dan wawancara yang telah dilakukan. (Riris Ning Pambudi 2014:41). Informan ditentukan dengan teknik Snowball, yaitu Koordinator Pegiat Wisata . Selanjutnya menggelinding ke informan yang ditunjuk sampai diperoleh kecukupan data. Sedangkan data sekunder diperoleh dari kepustakaan, media elektronik, dan Internet, serta jurnal. Analisis data dilakukan dengan cara kondensasi data, verifikasi data, dan konklusi data(Sugiyono, 2010). Untuk validasi data dengan menggunakan triangulasi sumber. Fenomena yang diamati adalah Model kerjasama yang dipakai dalam pengembangan pariwisata di kota Semarang, dilihat dari aktor yang terlibat dan perannya .

\section{HASIL DAN DISKUSI}

Upaya pengembangan kepariwisataan tidak mungkin dapat dilakukan tanpa campur tangan para stakeholder daerah. Pemerintah 
Kota Semarang berupaya untuk melakukan sinkronisasi kerjasama pengembangan kepariwisataan dengan berbagai pihak termasuk asosiasi pelaku pariwisata di kota Semarang, sehingga peran serta masyarakat dalam pengembangan kepariwisataan dapat semakin tumbuh dan terarah sesuai dengan kebijakan pemerintah. Yang dimaksud Pentahelix menurut Arif Yahya adalah kolaborasi 5 (Lima Unsur) unsur subjek atau stakeholder pariwisata, yaitu: Academician, Business, Community, Government dan Media. Biasa disingkat ABCGM. Pengembangan pariwisata Kota Semarang dari hasil penelitian menggunakan Model Pentahelix, yaitu melibatkan elemenelemen : Akademisi, Bisnis, Pemerintah (Goverment), Komunitas (Community) dan Media Massa.

Kemudian dalam implementasi kebijakan terdapat berbagai aktor yang terlibat. Mereka bisa berasal dari kalangan pemerintah maupun masyarakat, yang diidentifikasi berasal dari kalangan birokrasi, legislatif, lembaga peradilan, kelompok- kelompok penekan, dan organisasi-organisasi komunitas (James Anderson, 2003). Aktor yang terlibat dan peran mereka dari hasil penelitian ini dapat dijelaskan sebagai berikut.

\section{a.Identifikasi aktor yang terlibat}

Menurut Howlett dan M. Ramesh \{Howlett dan Rames (1995), dalam Suwitri(2011)\} mengemukakan bahwa aktor kebijakan (policy aktor) merupakan policy subsystem yang berada dalam jejaring kebijakan antara organization of the international system, organization of the society dan organization of the state. Aktor kebijakan terdiri atas : 1) elected officials yaitu eksekutif, legislatif, dan yudikatif, 2) appointed officials atau pejabat politik yang ditunjuk oleh pejabat politik terpilih untuk duduk dalam birokrasi, 3) interest group, 4) research organization, 5) media massa. Aktor-aktor tersebut saling berinteraksi untuk memberikan persetujuan (pro) maupun ketidaksetujuan (kontra) terhadap suatu kebijakan. Pendapat l a in dikemukakan Cobb dan Elder (1972 dalam Wayne Parsons, 1997: 128, 2005: 131). Cobb dan Elder mengemukakan bahwa aktor kebijakan terdiri dari pemerintah dan sekumpulan publik yang mengetahui dan tertarik dengan urusan publik dan yang mempunyai pemimpin opini, dan media massa yang menjadi pemicu bagi kuat lemahnya tekanan publik tersebut terhadap pemerintah agar suatu urusan publik tersebut (isu) menjadi policy output. Peran media massa sangat penting dalam membangkitkan perhatian, memprovokasi aksi, melemahkan penentangan, menunjukkan kekuatan komitmen dan dukungan. Berdasarkan hasil penelitian, diketahui bahwa aktor yang terlibat dalam pengembangan pariwisata kota Semarang terdiri dari 5 (lima) elemen yaitu : Elemen pertama adalah pemerintah (Government) meliputi: Disbudpar, Bappeda,Dishub, Disdag, DinKopUM, Diskominfo, SatpolPP Bi dang Pariwisata, Dinrumkim, DPU,Distan, Dintaru, BBWS, Pokdarwis, BP2KS, Kepolisian (SatPam ObVit) Elemen kedua adalah akademisi yang terdiri dari: Udinus, Unisbank, Stiepari. Elemen ketiga business adalah, meliputi ASITA, PHRI, KADIN, APPS. Elemen keempat komunitas terdiri dari, Dekase, Genpi, Kom. Blogger, Kom. Fotografi, Pegiat Wisata. Elemen kelima adalah media terdiri dari Wawasan, RRI Semarang, Elshinta FM, Cakra Semarang TV, Jateng post, TV KU, TVRI, Suara Merdeka. Untuk lebih jelasnya dapat dilihat pada gambar model pentahelix dibawah ini.

Gb. 1

Model Pengembangan Pariwisata Kota Semarang (Konsep Pentahelix)

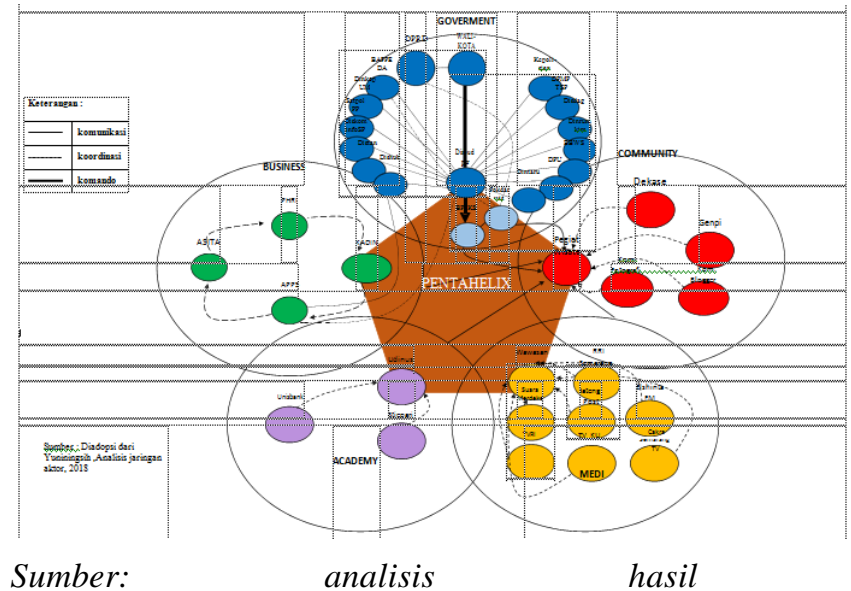

penelitian,(Yuniningsih,2018)

\section{b. Peran Aktor yang terlibat}

Government pada umumnya birokrasi dipandang sebagai agen administrasi yang paling bertanggungjawab dalam implementasi 
kebijakan.Pandangan ini berlaku untuk implementasi kebijakan Negara maju maupun Negara yang sedang berkembang (NSB). Birokrasi mempunyai wewenang yang besar untuk sepenuhnya menguasai "area" implementasi kebijakan dalam wilayah operasinya karena mereka mendapat mandat dari lembaga legislatif. Aktor yang terlibat dan teridentifikasi dari elemen pertama yaitu Pemerintah adalah : Disbudpar, Bappeda,Dishub,Disdag, DinKopUM, Diskominfo, Satpol PP Bi dan Pariwisata, Dinrumkim, DPU,Distan, Dintaru, BBWS, Pokdarwis, BP2KS, Kepolisian (SatPam ObVit). Dari hasil penelitian dapat diketahui bahwa peran masing - masing aktor adalah sebagai berikut:

\begin{tabular}{|c|c|c|c|}
\hline $\mathrm{N}$ & Aktor & Peran & Relasi \\
\hline 1. & $\begin{array}{l}\text { Disbudpa } \\
\mathrm{r}\end{array}$ & $\begin{array}{l}\text { Urusan } \\
\text { Bidang } \\
\text { Kebudayaan } \\
\text {, Kesenian, } \\
\text { Pembinaan } \\
\text { Industri } \\
\text { Pariwisata, } \\
\text { Pemasaran } \\
\text { (Promosi) }\end{array}$ & $\begin{array}{l}\text { Sesuai } \\
\text { tupoksi }\end{array}$ \\
\hline 2. & Bappeda & $\begin{array}{l}\text { Perencanaan } \\
\text { Pengemban } \\
\text { gan } \\
\text { Pariwisata } \\
\text { yang } \\
\text { tersusun } \\
\text { dalam } \\
\text { Renstra } \\
\text { Kota } \\
\text { Semarang }\end{array}$ & $\begin{array}{l}\text { Sesuai } \\
\text { tupoksi }\end{array}$ \\
\hline 3. & Dishub & $\begin{array}{l}\text { Penyedia } \\
\text { akses dan } \\
\text { infrastruktur } \\
\text { berkaitan } \\
\text { dengan } \\
\text { kepariwisata } \\
\text { an }\end{array}$ & $\begin{array}{l}\text { Pengadaan } \\
\text { bus kenang, } \\
\text { mestinya } \\
\text { dalam } \\
\text { tupoksi } \\
\text { disbudpar }\end{array}$ \\
\hline 4. & Disdag & $\begin{array}{l}\text { Memfasilita } \\
\text { si bidang } \\
\text { industri dan } \\
\text { perdaganga } \\
\mathrm{n}\end{array}$ & $\begin{array}{l}\text { Sesuai } \\
\text { tupoksi }\end{array}$ \\
\hline 5. & DPU & $\begin{array}{l}\text { Memfasilita } \\
\text { si sarana } \\
\text { dan } \\
\text { prasarana } \\
\text { jalan }\end{array}$ & $\begin{array}{l}\text { Sesuai } \\
\text { tupoksi }\end{array}$ \\
\hline
\end{tabular}

\begin{tabular}{|c|c|c|c|}
\hline 6. & $\begin{array}{l}\text { Dinrumki } \\
\mathrm{m}\end{array}$ & $\begin{array}{l}\text { Memfasililt } \\
\text { asi dalam } \\
\text { hal } \\
\text { homestay, } \\
\text { penginapan }\end{array}$ & $\begin{array}{l}\text { Sesuai } \\
\text { tupoksi }\end{array}$ \\
\hline 7. & Distan & $\begin{array}{l}\text { Memfasilita } \\
\text { si bidang } \\
\text { pertanian }\end{array}$ & $\begin{array}{l}\text { Sesuai } \\
\text { tupoksi }\end{array}$ \\
\hline 8. & Dintaru & $\begin{array}{l}\text { Memfasilita } \\
\text { si bidang } \\
\text { tata ruang }\end{array}$ & $\begin{array}{l}\text { Sesuai } \\
\text { tupoksi }\end{array}$ \\
\hline 9. & $\begin{array}{l}\text { DinKOP } \\
\text { UM }\end{array}$ & $\begin{array}{l}\text { Memfasilita } \\
\text { si bidang } \\
\text { koperasi } \\
\text { dan UMKM }\end{array}$ & $\begin{array}{l}\text { Belum } \\
\text { optimal } \\
\text { dalam } \\
\text { mengemban } \\
\text { gkan }\end{array}$ \\
\hline 10 & $\begin{array}{l}\text { DPMPTS } \\
\mathrm{P}\end{array}$ & $\begin{array}{l}\text { Memfasilita } \\
\text { si bidang } \\
\text { penanaman } \\
\text { modal dan } \\
\text { pelayanan } \\
\text { perijinan } \\
\text { terpadu satu } \\
\text { pintu }\end{array}$ & $\begin{array}{l}\text { Sesuai } \\
\text { tupoksi }\end{array}$ \\
\hline 11 & BBWS & $\begin{array}{l}\text { Memfasilit } \\
\text { asi area } \\
\text { yang } \\
\text { menjadi } \\
\text { wilayah } \\
\text { kerjanya }\end{array}$ & $\begin{array}{l}\text { konflik } \\
\text { (gesekan) } \\
\text { kepentingan } \\
\text { dengn } \\
\text { Pokdarwis } \\
\text { sekitar }\end{array}$ \\
\hline 12 & Satpol PP & $\begin{array}{l}\text { Penegkan } \\
\text { peraturan } \\
\text { dan } \\
\text { penertiban } \\
\text { wilayah } \\
\text { sekitar } \\
\text { objek } \\
\text { wisata }\end{array}$ & $\begin{array}{l}\text { sesuai } \\
\text { tupoksi }\end{array}$ \\
\hline 13 & BP2KS & $\begin{array}{l}\text { Memberik } \\
\text { an ide } \\
\text { dan } \\
\text { gagasan } \\
\text { promosi } \\
\text { wisata } \\
\text { Kota } \\
\text { Semarang }\end{array}$ & $\begin{array}{l}\text { belum } \\
\text { optimal } \\
\text { kinerjanya }\end{array}$ \\
\hline 14 & $\begin{array}{l}\text { Pokdarwi } \\
\text { s }\end{array}$ & $\begin{array}{l}\text { ujung } \\
\text { tombak } \\
\text { pengemba } \\
\text { ngan } \\
\text { wisata di } \\
\text { level } \\
\text { terbawah }\end{array}$ & $\begin{array}{l}\text { tingkat } \\
\text { inisiatifnya } \\
\text { rendah }\end{array}$ \\
\hline
\end{tabular}


Sumber : Analisis peneliti (Yuniningsih,2018)

Badan Legislatif, walaupun birokrasi merupakan aktor utama dalam implementasi kebijakan publik, sejumlah aktor lain dan lembaga juga terlibat di dalam prosesnya. Aktor selain birokrasi adalah Legislatif. Lembaga legislatif juga dapat terlibat dalam implementasi kebijakan ketika mereka ikut menentukan berbagai peraturan yang spesifik dan mendetail. Aktor yang dimaksud adalah DPRD kota Semarang. Dari hasil penelitian dapat diketahui bahwa peran aktor legislatif adalah sebagai berikut:

\begin{tabular}{|l|l|l|}
\hline aktor & Peran & Realisasi \\
\hline DPRD & $\begin{array}{l}\text { Legalisasi, } \\
\text { budgeting, } \\
\text { controlling }\end{array}$ & $\begin{array}{l}\text { Sesuai } \\
\text { tupoksi }\end{array}$ \\
\hline
\end{tabular}

Sumber : Analisis peneliti (Yuniningsih,2018)

$$
\text { Lembaga Peradilan, disamping }
$$

legislatif, lembaga peradilan juga merupakan aktor dalam implementasi kebijakan.Lembaga peradilan merupakan cabang yudisial yang menangani hukum publik.Namun lembaga peradilan dapat terlibat dalam implementasi kebijakan ketika muncul tuntutan masyarakat atas kebijakan tertentu yang implementasinya dianggap merugikan masyarakat sehingga menjadi perkara hukum. Lembaga yang dimaksud adalah Kepolisian (SatPam ObVit) dan SatpolPP Bidang Pariwisata. Dari hasil penelitian dapat diketahui bahwa peran masing - masing aktor adalah sebagai berikut :

\begin{tabular}{|l|l|l|l|}
\hline No. & Aktor & Peran & Realisasi \\
\hline 1. & Satpol PP & $\begin{array}{l}\text { Penegkan } \\
\text { peraturan dan } \\
\text { penertiban } \\
\text { wilayah } \\
\text { sekitar objek } \\
\text { wisata }\end{array}$ & $\begin{array}{l}\text { Sesuai } \\
\text { tupoksi }\end{array}$ \\
\hline 2. & $\begin{array}{l}\text { Kepolisian } \\
\text { Pariwisata }\end{array}$ & $\begin{array}{l}\text { pengamanan } \\
\text { dan } \\
\text { kenyamanan } \\
\text { pada objek } \\
\text { dan } \\
\text { wisatawan }\end{array}$ & $\begin{array}{l}\text { Sesuai } \\
\text { tupoksi }\end{array}$ \\
\hline
\end{tabular}

Sumber : Analisis peneliti (Yuniningsih,2018)

Research Organization / akademisi, Lembaga lain yang sering terlibat dalam implementasi kebijakan adalah akademisi. Banyak program-program yang dirancang untuk melaksanakan kebijakan-kebijakan politik yang berlabel pro pembangunan masyarakat (community development). Para akademisi memiliki kepakaran dan sebagai lembaga penelitian maka memiliki peran yang penting .Dengan sendirinya akademisi akan turut terlibat dalam implementasi kebijakan.. Aktor yang terlibat dan teridentifikasi dari elemen ini adalah STEPARI, UNISBANK, DAN UDINUS. Dari hasil penelitian dapat diketahui bahwa peran masing - masing aktor adalah sebagai berikut:

\begin{tabular}{|l|l|l|l|}
\hline No. & Aktor & Peran & Realisasi \\
\hline 1. & Stiepari & $\begin{array}{l}\text { Lembaga } \\
\text { research }\end{array}$ & $\begin{array}{l}\text { Belum } \\
\text { ada riset } \\
\text { yang } \\
\text { berkaitan }\end{array}$ \\
\hline 2. & Unsibank & $\begin{array}{l}\text { Lembaga } \\
\text { research }\end{array}$ & $\begin{array}{l}\text { Lembaga } \\
\text { research }\end{array}$ \\
\hline 3. & Udinus & . & \\
\hline
\end{tabular}

Sumber : Analisis peneliti (Yuniningsih,2018)

Bisnis, sebagai entrepreneur harus dimanfaatkan untuk pengembangan bisnis untuk mencapai tujuan bisnis yaitu : profit, people, planet, sustainability serta tumbuh dan berkembag dari skala mikro, kecil, menengah, dan besar. Sudah saatnya entrepreneur untuk memanfaatkan konsep yang dihasilkan oleh para akademisi dengan seminar dan diskusi. Aktor yang terlibat dan teridentifikasi dari elemen ini adalah:

\begin{tabular}{|c|c|c|c|}
\hline No. & Aktor & Peran & Realisasi \\
\hline 1. & PHRI & $\begin{array}{l}\text { memberikan } \\
\text { ide gagasan } \\
\text { dan masukan } \\
\text { kepada leading } \\
\text { sector, serta } \\
\text { Pengelolaan } \\
\text { hotel dan } \\
\text { restoran }\end{array}$ & $\begin{array}{l}\text { Sesuai } \\
\text { peran }\end{array}$ \\
\hline 2. & ASITA & $\begin{array}{l}\text { memberikan } \\
\text { ide gagasan } \\
\text { dan masukan } \\
\text { kepada leading } \\
\text { sector, serta } \\
\text { Koordinator } \\
\text { biro perjalanan } \\
\text { dan travel }\end{array}$ & $\begin{array}{l}\text { sesuai } \\
\text { peran, } \\
\text { diharapkan } \\
\text { mampu } \\
\text { membuat } \\
\text { paket } \\
\text { wisata }\end{array}$ \\
\hline 3. & PUTRI & $\begin{array}{l}\text { memberikan } \\
\text { ide gagasan } \\
\text { dan } \\
\text { masukan }\end{array}$ & $\begin{array}{l}\text { Sesuai } \\
\text { peran }\end{array}$ \\
\hline
\end{tabular}




\begin{tabular}{|l|l|l|}
\hline & $\begin{array}{l}\text { kepada } \\
\text { leading } \\
\text { sector }\end{array}$ & \\
\hline
\end{tabular}

Sumber : Analisis peneliti (Yuniningsih,2018)

Community, aktor lainnya yang berperan dalam implementasi adalah kelompokkelompok atau komunitas. Karena dalam implementasi berbagai diskresi banyak dilakukan oleh birokrasi,maka banyak kelompok-kelompok yang ada di masyarakat berusaha mempengaruhi berbagai peraturan implementasi seperti pedoman acuan atau regulasi- regulasi. Tindakan kelompok-kelompok dimaksudkan agar mereka memperoleh keuntungan dengan adanya implementasi program tertentu. Aktor yang terlibat dan teridentifikasi dari elemen ini adalah:

\begin{tabular}{|c|c|c|c|}
\hline No & Aktor & Peran & Realisasi \\
\hline 1. & Dekase & $\begin{array}{l}\text { memberika } \\
\mathrm{n} \text { ide } \\
\text { gagasan } \\
\text { dan } \\
\text { masukan } \\
\text { kepada } \\
\text { leading } \\
\text { sector, } \\
\text { sekaligus } \\
\text { koordinato } \\
\text { r kesenian } \\
\text { diluar } \\
\text { Pemerinta } \\
\text { h }\end{array}$ & Sesuai peran \\
\hline $\begin{array}{l}\text { No } \\
\text {. }\end{array}$ & Aktor & Peran & Realisasi \\
\hline 1. & GenPi & $\begin{array}{l}\text { Promosi } \\
\text { destinasi } \\
\text { dan event } \\
\text { wisata } \\
\text { Kota } \\
\text { Semarang }\end{array}$ & Sesuai peran \\
\hline 2. & $\begin{array}{l}\text { Pegiat } \\
\text { Wisata }\end{array}$ & $\begin{array}{l}\text { memberika } \\
\mathrm{n} \text { ide } \\
\text { gagasan } \\
\text { dan } \\
\text { masukan } \\
\text { kepada } \\
\text { leading } \\
\text { sector }\end{array}$ & $\begin{array}{l}\text { Aktif dalam } \\
\text { pengembang } \\
\text { an pariwisata }\end{array}$ \\
\hline 3. & $\begin{array}{l}\text { Komunit } \\
\text { as } \\
\text { Fotografi }\end{array}$ & $\begin{array}{l}\text { Promosi } \\
\text { destinasi } \\
\text { dan } \\
\text { event } \\
\text { wisata Kota } \\
\text { Semarang }\end{array}$ & Sesuai peran \\
\hline
\end{tabular}

\begin{tabular}{|l|l|l|l|}
\hline & & $\begin{array}{l}\text { di bidang } \\
\text { fotografi } \\
\text { dan bersifat } \\
\text { independen }\end{array}$ & \\
\hline 4. & Blogger & $\begin{array}{l}\text { Promosi } \\
\text { destinasi } \\
\text { dan } \\
\text { event } \\
\text { wisata Kota } \\
\text { Semarang } \\
\text { di pada } \\
\text { situs web } \\
\text { dan bersifat } \\
\text { independen }\end{array}$ & \\
& & Sesuai peran & \\
& & \\
\end{tabular}

Sumber : Analisis peneliti (Yuniningsih,2018)

Media Massa, merupakan penghubung penting antara negara dan masyarakat, perpaduan reporter pasif dan analis aktif memiliki tempat tersendiri dalam proses kebijakan publik untuk memberikan ruang bagi pemerintah dan masyarakat dalam memahami masalah sosial sekaligus untuk memecahkan permasalahan sosial tersebut. Aktor yang terlibat dan teridentifikasi dari elemen kelima ini adalah:

\begin{tabular}{|c|c|c|c|}
\hline No. & Aktor & Peran & $\begin{array}{l}\text { Realisas } \\
\text { i }\end{array}$ \\
\hline 1. & Wawasan & \multirow{3}{*}{$\begin{array}{l}\text { Publikasi } \\
\text { informasi } \\
\text { kepariwisataa } \\
\text { n melalui } \\
\text { media cetak }\end{array}$} & $\begin{array}{l}\text { Sesuai } \\
\text { peran }\end{array}$ \\
\hline 2. & $\begin{array}{l}\text { Jateng } \\
\text { post }\end{array}$ & & $\begin{array}{l}\text { Sesuai } \\
\text { peran }\end{array}$ \\
\hline 3. & $\begin{array}{l}\text { Suara } \\
\text { merdeka }\end{array}$ & & $\begin{array}{l}\text { Sesuai } \\
\text { peran }\end{array}$ \\
\hline 4. & RRI & \multirow{2}{*}{$\begin{array}{l}\text { Publikasi } \\
\text { informasi } \\
\text { kepariwisataan } \\
\text { melalui media } \\
\text { radio }\end{array}$} & $\begin{array}{l}\text { Sesuai } \\
\text { peran }\end{array}$ \\
\hline 5. & $\begin{array}{l}\text { Elshinta } \\
\text { FM }\end{array}$ & & $\begin{array}{l}\text { Sesuai } \\
\text { peran }\end{array}$ \\
\hline 6. & $\begin{array}{l}\text { TVRI } \\
\text { jateng }\end{array}$ & \multirow{3}{*}{$\begin{array}{l}\text { Publikasi } \\
\text { informasi } \\
\text { kepariwisataan } \\
\text { melalui media } \\
\text { televisi }\end{array}$} & $\begin{array}{l}\text { Sesuai } \\
\text { peran }\end{array}$ \\
\hline 7. & TV KU & & $\begin{array}{l}\text { Sesuai } \\
\text { peran }\end{array}$ \\
\hline 8. & $\begin{array}{l}\text { Cakra } \\
\text { Semaran } \\
\text { g TV }\end{array}$ & & $\begin{array}{l}\text { Sesuai } \\
\text { peran }\end{array}$ \\
\hline
\end{tabular}

Sumber: Analisis peneliti (Yuniningsih,2018)

\section{KESIMPULAN}

a. Pengembangan pariwisata kota Semarang menggunakan model pentahelix, dimana sudah melibatkan 5(lima) elemen yaitu: akademisi, pemerintah, komunitas, bisnis, dan media massa. Dari hasil penelitian 
diketahui bahwa elemen komunitas (pegiat wisata) memiliki peran yang sangat strategis yaitu suatu kelompok yang mampu mengkoordinir semua elemen dalam pengembangan pariwisata kota Semarang.

b. Temuan lapangan yang diperoleh adalah Badan Promosi Pariwisata Kota Semarang (BP2KS) belum optimal dalam menjalankan tugasnya sebagai badan yang dibentuk dan didanai pemerintah untuk membantu promosi pariwisata.

c. Kerjasama antar aktor dalam model pentahelix yang ada di kota Semarang dari hasil penelitian belum optimal mengingat masih ada kecenderungan aktor - aktor yang berjalan sendiri - sendiri, selain itu masih adanya ketidakpercayaan antar aktor.

Rekomendasi

a. Dalam rangka mengoptimalkan model pentahelix pengembangan pariwisata dikota
Semarang maka perlu dilakukan revisi terhadap regulasi/ perda kepariwisataan kota Semarang yang menyangkut "kerjasama antar aktor".

b. Perlunya penguatan kapasitas kelembagaan BP2KS sebagai badan yang membantu mempromosikan pariwisata kota Semarang dan coordinator semua aktor yang terlibat dalam pengembangan pariwisata.

c. Untuk peneliti berikutnya disarankan mengambil fokus penelitian dengan lokus yang berbeda atau melakukan perbandingan dengan fokus yang sama.

\section{UCAPAN TERIMA KASIH}

Ucapan terima kasih disampaikan kepada Walikota Semarang beserta jajarannya, Kepala Dinas Kebudayaan dan Pariwisata Semarang, Community, Bisnis, dan media massa, serta semua informan yang telah bersedia membantu dalam penelitian ini yang tidak dapat saya sebutkan satu persatu, 


\section{DAFTAR PUSTAKA}

Sugiyono. 2010. Metode Penelitian Administrasi. Bandung : Alfabeta

Anderson, James E, 2006, Public Policy Making: An Introduction, Boston: Houghton Muffin Company.

Howlett, Michael, dan M. Ramesh. (1995). Studying Public Policy: Policy Cycles and Policy Subsystem. Oxford: University Press

Sugiyono, 2014, Metode Penelitian Administrasi, Penerbit Alfabetha Bandung.

Meitisa Vanya Simanjuntak. 2015. Analisis Jaringan Aktor Dalam Perlindungan Anak di Kota Semarang. Tesis. Magister Ilmu Administrasi Fakultas Ilmu Sosial dan Ilmu Politik Universitas Diponegoro.

Suwitri, Sri. 2008. Konsep Dasar Kebijakan Publik. Undip. Semarang. 2011,Jejaring Kebijakan Dalam Perumusan Kebijakan Publik: Suatu Kajian Perumusan Kebijakan Penanggulangan Banjirdan Rob Pemerintah Kota Semarang, Badan Penerbit Universitas Diponegoro, Semarang.

Yuniningsih, Tri. 2018, Analisis Jaringan Aktor dalam Kebijakan Pengembangan Pariwisata Kota Semarang, Desertasi. Program Studi Doktor Administrasi Publik Fakultas Ilmu Sosial dan Ilmu Politik Universitas Diponegoro.

Dang Wang, John Ap, 2013, Faktor Affecting Tourism Policy Implementation: Conceptual Framework and Case Study in China. Journal of Tourism Management, (36), 221-233.

Chui, Hua Lie et al., 2012, Improving Tourism Policy Implementation : The Use of Hybrid MCDM Model, Tourism Management, (33), 413-426.

Victoria M. Waligo, Jackie Clarke, Rebecca Hawkin, 2012, Implementing Sustainable Tourism: Multi Stakeholder Involvement Management (MSIM) Framework, Tourism Managemant, 30, 1-12.

Albert N. Kimbu and Michael Z. Ngoasong, 2013, Centralized Decentralization of Tourism Development : A Netrwork Perspective, Annals of Tourism Research, vol. 10, 235-259.

Tobias Bach (2012), The involvement of agencies in policy formulation : Explaining variation in policy autonomy offederal agencies in Germany.

Meitisa Vanya Simanjuntak (2015), Analisis Jaringan Aktor Dalam Perlindungan Anak di Kota Semarang.

Lembar Peraturan Daerah Kota Semarang No 3 tahun 2010 tentang Kepariwisataan

Lembar Peraturan Daerah Kota Semarang Nomor 6 Tahun 2010 tentang Rencana Pembangunan Jangka Panjang Daerah Kota Semarang Tahun 2005-2025

Lembar Peraturan Walikota Semarang No 2 tahun 2012 tentang Badan Promosi Pariwisata Kota Semarang 
Tri Yuningsih: Model Pentahelik Dalam Pengembangan.. 